\title{
Domesticating Animals in Africa: Implications of Genetic and Archaeological Findings
}

\author{
Diane Gifford-Gonzalez • Olivier Hanotte
}

Published online: 6 February 2011

(C) The Author(s) 2011. This article is published with open access at Springerlink.com

\begin{abstract}
Domestication is an ongoing co-evolutionary process rather than an event or invention. Recent zooarchaeological and animal genetics research has prompted a thorough revision of our perspectives on the history of domestic animals in Africa. Genetic analyses of domestic animal species have revealed that domestic donkeys are descended from African ancestors, opened a debate over the contribution of indigenous aurochs to African domestic cattle, revealed an earlier and possibly exogenous origin of the domestic cat, and reframed our vision of African dogs. Genetic diversity studies and mapping of unique traits in African cattle, sheep, goats, pigs and chickens indicate adaptations to regional environmental challenges and suggest hitherto unknown and complex patterns of interactions both among Africans and with Southwest Asia and other Asian regions on the Indian Ocean. This article argues against the static perspective on domestication as invention and for viewing it as a dynamic, locally based and continuing process.
\end{abstract}

Keywords Africa $\cdot$ Domestication $\cdot$ Genetics $\cdot$ Zooarchaeology $\cdot$ Co-evolution

\section{Introduction}

Zooarchaeologists working in Africa are sometimes asked by laypersons why Africans never domesticated any of its abundant wildlife. Today one can respond that genetic evidence indicates that some domestic species indeed originated in Africa, but the question itself reveals implicit assumptions that repay further attention. In the first place, it implies

D. Gifford-Gonzalez (ه)

Department of Anthropology, University of California, Santa Cruz, CA 95064, USA

e-mail: dianegg@ucsc.edu

O. Hanotte

The School of Biology, Centre for Genetics and Genomics, The University of Nottingham, University Park, Nottingham NG7 2RD, UK 
that domestication is a milestone of human progress, which Africans may not have passed, while groups that domesticated plants or animals earliest have. Few archaeologists today would support such nineteenth century claims that people's intellectual progress can be diagnosed from their technology, but the privileging of oldest occurrences persists as a leitmotif in archaeological research, which Stahl (1999) asserts coincides with the progressivist rhetoric that endures in funding agencies and mass media, where inventiveness still distinguishes 'advancement.'

More pertinently to this review, the question treats domestication as an invention, rather than as an ongoing biological process. The title of this article deliberately chooses the gerund form of the verb 'to domesticate' to delineate the dynamic and continuous nature of the process. The view of domestication as invention also presumes that all animals are equally domesticable 'raw materials,' overlooking their physiological and behavioral diversity and how this interacts with human manipulation. Taming of individual animals may be a first step in increasing human control of physical and behavioral traits, but it alone does not necessarily produce long-term evolutionary effects. Ancient Egyptian art depicts monkeys picking fruit for their handlers, and gazelles tame enough to be led by a halter. However, these animals left no progeny substantially divergent in behavior or form from their wild type (Linseele 2010). Many endangered species in zoos and other facilities accept penning and respond to training cues yet fail to reproduce as captives. Selection for or against specific physical and behavioral traits operates at the populational level, and over generations. Some species that began as commensals in human settlements may not have been tamed early in their domestication process, but instead evolved over generations to tolerate proximity to humans. Some selection may, as in such cases, result from the demands of an increasingly mutualist relationship between humans and another species rather than from deliberate taming or manipulation by people. However, in all cases the domestication process operates at the level of an animal population engaged behaviorally with humans (O'Connor 1997). Those species that tolerated human proximity, prospered, and, most importantly, bred under human management became domesticates.

Viewing domestication as an invention also produces a profound lack of curiosity about evolutionary changes in domestic species after their documented first appearances. Marshall (2000, pp. 205-206) notes that archaeologists studying trade and urbanization may consider domestic species as a necessary but uninteresting part of societal infrastructure, once the first-appearance Rubicon has been crossed, whilst zooarchaeologists have a different vision of such mutualisms. Albarella et al. (2006) assert that medieval pigs are as informative to their study of suid domestication as are their Neolithic precursors, because co-evolutionary changes are continuous, with new circumstances imposing new selective pressures. In fact, ignoring the co-evolution of species in settled, complex societies marginalizes a vast amount of relevant historical information, which may be especially pertinent to modern descendant communities dealing with social and environmental changes.

O'Connor (1997) and Russell (2002) have reviewed definitions of domestication, noting those emphasizing domination as well as social and cultural dimensions of this process and, ultimately, human management of its course. However, from the perspective of genetics, a definition that emphasizes the co-evolutionary aspects of the process is more pertinent to this overview. Subsequent sections briefly review domestication as a form of co-evolution, how zooarchaeologists have diagnosed domestication and how genomics has revolutionized this field, and finally, our present state of knowledge of nine species with considerable antiquity as domesticates in Africa. 


\section{Domestication as a Co-evolutionary Process}

Humans and their domesticates exist in the symbiotic relationship of mutualism, as each species benefits from the other, in terms of its reproductive success. A form of co-evolution, domestication results from both intentional human intervention in the reproduction of another species and from selection operating in environments largely structured by humans (cf. Albarella et al. 2006). It continues with each generation, as humans, plants and animals interact and certain phenotypic forms and behaviors are selected for.

Humans as well as animals alter their behavior in relation to each other. In some cases, human gene frequencies change in this relationship, as illustrated by the mutation for lactase persistence, enabling milk digestion, into adulthood. The highest frequencies of the Eurasian mutation for lactase persistence coincide geographically with peaks in alleles favoring increased milk protein production among cows, reflecting selection for advantageous mutations in both species in the context of dairying (Beja-Pereira et al. 2004). Several other genetic mutations for lactase persistence have recently been defined among East African populations, differing from but paralleling the European co-evolutionary case (Tishkoff et al. 2007), as will be discussed in greater detail later.

The view of domestication as a singular, intentional invention is at odds with examples of what Zohary et al. (1998) called 'unconscious selection.' As humans control animals' foraging choices, exposure to predators, and mate choice, as well as moving them into novel environmental situations, they may inadvertently alter selective contexts and pressures. The genetic origins of such changes in male sheep and goat horns are now considered as initially unplanned byproducts of human management (Zeder 2006). Horns are energetically costly structures that are continuously selected for among wild males, which compete for rank, and thus for access to mates, by clashing heads and sparring with their horns. When human choice, rather than horn size, came to determine males' reproductive success, selective pressure for horn size relaxed. Mutations for smaller horns, which would never have favored reproductive success in the wild, emerged among later generations, allowing the bearers to divert energy into other fitness-enhancing channels, such as earlier sexual maturity and higher sperm production. Similarly, the diversity of coat color in pigs is the result initially of relaxed natural selection pressure on the coat pattern of domesticated wild boar (Fang et al. 2009).

A recent example of 'unconscious selection' emerged in a research colony of silver morph red foxes, Vulpes vulpes, managed by the Institute of Cytology and Genetics (Trut 1999) in Novosibirsk, Russia. From 1959, managers of the founding stock of 130 individuals selectively bred one line from animals that most tolerated captivity and human contact in each generation, while another, 'control' line was allowed to retain the fearaggression responses typical of captive wild foxes. Within ten generations, about $20 \%$ of the human-tolerant bloodline displayed considerable friendliness toward humans, seeking attention in a dog-like manner, barking, tail-wagging, jumping up, and licking (Trut 1999; Kukekova et al. 2006). Notably, the 'friendly' line also saw unforeseen physical changes, specifically pups born with white blazes on faces and chests and curling tails, traits that distinguish dogs from wolves. ICG breeders had not deliberately selected for any such traits. The specific genetic and physiological causes of these new phenotypes are still under investigation, but this is clearly a documented case of 'unconscious selection.'

Returning to that initial question of why African animals were not domesticated, modern experiments have demonstrated that many African ungulate species are unsuited to close human management. Penned gazelles panic and may mortally injure themselves or other animals in trying to escape (Spinage 1986). Males of some antelope species establish and maintain small individual territories, or leks, which estrous females enter to mate; 
human herding and penning disrupts this, interfering with the species' reproduction (Walther 1972). Domestic ungulates are not descended from lek breeders, instead being organized in dominance hierarchies, with highest-ranking males joining female herds during the mating season. Humans manipulate this reproductive strategy by choosing the breeding male and castrating or slaughtering the others.

African bovids such as the sheep-like aoudad Ammotragus lervia and some savanna antelopes and wild equines display dominance-based social organization and reproductive ecology, the eland being successfully tamed and managed for many generations in the twentieth Century (Nowak 1991). Evidence from late 7th millennium BC southwestern Libya suggests that some African foragers, perhaps prompted by regional desiccation, did initiate experiments with keeping aoudads (Di Lernia 2001). At the Uan Afuda cave, foragers penned a herd of Ammotragus in the back of the cave, possibly narcotizing them with leaves of a local shrub, and used them for food. Such manipulation did not result in domestication. However, cattle-keeping appears in northeastern Africa in the next millennium: the Nubian wild ass was domesticated between the 5th and 4th millennia BC, and sheep and goats were introduced into the same region around $5000 \mathrm{BC}$. Thus, African foragers were actively and successfully manipulating indigenous and exogenous stock, bringing at least one such lineage into a domestic state, over the early to middle Holocene.

\section{Approaches to Diagnosing Domestication in Animals}

Although zooarchaeologists have tended to view domestication as an ongoing co-evolutionary process, the synergy between zooarchaeology and modern animal genetics has produced a quantum shift in animal domestication studies. Before modern DNA amplification and sequencing techniques were applied to animal domestication, zooarchaeologists took three approaches to diagnosing it, all based on the study of bone elements, only one of which has been shown to be reliably diagnostic of early domestication. Morphological analysis to diagnose domestication suffers from the fact that animals in incipient phases of domestication will by definition exhibit wild phenotypes. Metrical analysis rests on the assumption that size reduction is a universal characteristic of mammalian domestication, and this has recently been called into question by thorough comparative study (Zeder 2006). Demographic profile analysis diagnoses domestication from mortality profiles constructed from archaeological samples. Young-dominated age-at-death profiles are common in early farming, diverging from prime-age dominated ones typical of hunting by humans. This approach is the most dependable for defining the earliest phases of domestication from preserved physical remains (Zeder et al. 2006; Zeder and Hesse 2000).

Modern genomics offers two methods for elucidating the ancestry and relationships of domesticates, by allowing studies of the present and past genetic make-up of domesticates.

Modern DNA analysis compares the degree of similarity in several types of nuclear and/ or cytoplasmic genetic markers within and amongst populations. This permits identification of wild ancestral species, subspecies, or populations, geographic center(s) of origin, evolutionary bottlenecks and expansions, and consistent hybridizations, or introgressions, between related species, as well as geographic expansions and migrations.

Various genetic markers provide complementary information. Mitochondrial DNA, nearly exclusively maternally inherited, is the genetic marker of choice for unraveling domestication events, because successful domestication means successful captive breeding (Hanotte 2007). Each individual mitochondrial DNA sequence is referred to as a haplotype. Closely related haplotypes can be grouped within haplogroups, also called clades. 
The presence of distinct haplogroups within a domesticated species has been used to infer distinct domestication events in different regional populations. This inference is especially compelling where the haplogroups are predominantly found in geographically separated areas in the wild ancestral range, and when they reflect a divergence from a common ancestor at much earlier times than the estimated age of domestication, as has been shown for zebu (humped) versus taurine (straight-backed) cattle, as well as for European and Asian pigs (Pérez-Pardal et al. 2010).

In mammals the paternally inherited $Y$ chromosome can be used in a similar manner to trace the number of male lineages that contributed to a domestic species. $Y$-DNA has been used to address the question of domestic or wild male introgression in livestock populations (e.g. Götherström et al. 2005).

Nuclear microsatellites, or tandem repeats, are small, repeating sequences of base pairs and are both paternally and maternally inherited. These can be distinctive to regional populations, being particularly powerful for tracing the history of movements of domesticated populations from their regions of origin (Hanotte et al. 2002).

Modern DNA studies possess two drawbacks. First, they provide only information on the present genetic make-up of a species, which may be an incomplete picture of past variability. Second, dating domestication processes using modern DNA data alone remains a challenge, given the uncertainty associated with the estimation of the molecular clocks which might be species and/or gene specific and which often will require independent calibration (e.g. Kumar 2005). Nevertheless, it can be expected that modern DNA studies will continue to play an important role in our understanding of the pattern and process of livestock domestication. Particularly promising are the applications of whole genome sequencing, which is already opening the door to identification and studies of loci selected during livestock domestication (Rubin et al. 2010).

Ancient DNA (aDNA) analysis balances these drawbacks by providing insights into domesticates' genetic diversity in the past, allowing study of now-extinct ancestral populations. It is based on amplification and analysis of genetic material extracted from bones, teeth, or eggshells. However, aDNA research has several drawbacks. It must cope with nucleic acid degradation over time, limiting the quantity and the fragment length of base pairs recoverable. Bacterial and fungal DNA may contaminate genetic material extracted from archaeological specimens. Extreme precautions must be taken in both field and laboratory to prevent between-sample or modern DNA contamination. Last but not least, ancient DNA conservation is highly dependent upon the environment, with arid zones being less favorable (Edwards et al. 2004). Nevertheless, aDNA studies have addressed important questions, including the possible contribution of extinct wild populations to the modern domesticates' gene pool (Kimura et al. 2010), and past diversity in domestic stock subsequently lost over their breeding history (Fernández et al. 2006).

Genetic research in Africa is less fully developed than in Europe, however, important data on the history of African breeds have been recovered from a combination of approaches. The next section synthesizes zooarchaeological and genetic data on major domesticated species in Africa, noting traits of modern breeds that reflect the co-evolutionary changes undergone in Africa.

\section{'Domesticating Animals in Africa': The Current State of Knowledge}

By the mid-6th millennium BC, cattle, sheep, and goats were found together across the savannas of what is now the Sahara, and it may be tempting to see these as a 'package,' 
perhaps introduced together from Southwest Asia. Yet, the earliest extant evidences suggest that these species appeared in Africa neither simultaneously, nor in the same places. One major impediment to closely tracing early livestock histories is the unfortunately common practice in Africanist zooarchaeological analyses of a priori lumping most sheep and goat remains into a 'caprine' or 'ovicaprine' category, without efforts to distinguish those elements that can be reliably assigned to particular species. Sheep and goats are very closely related, and many bone elements, especially when fragmentary, cannot be distinguished at the specific level. However, sheep are grazers, goats are browsers, are behaviorally divergent, and require different herding and handling tactics, and any hints of their relative proportions should be pursued. A closer study of how Africans interacted with these taxa in deep time now demands more attention to sorting the sheep from the goats. This task is greatly facilitated by more recent publications that permit more reliable distinctions than previously (cf. Balasse and Ambrose 2005; Zeder and Pilaar 2010; Helmer 2000; Halstead et al. 2002).

Cattle

Whether an independent domestication from now-extinct North African wild aurochs, Bos primigenius africanus, occurred in that region is as yet unresolved. Modern mitochondrial and $Y$-chromosome DNA do demonstrate independent domestications of indicine humped cattle in South Asia and of taurine straight-backed cattle in Southwest Asia (Loftus et al. 1994; Heindleder et al. 2008). A distinctive African mtDNA haplogroup, T1, in modern breeds initially led researchers to posit an independent domestication from the wild North African aurochs (Bradley et al. 1996; Bradley and Loftus 2000; Edwards et al. 2004), which is more closely related to the Southwest Asian form. More recently, debate has emerged over the meaning of this variation, because the commonest African and Southwest Asian haplotype, the T3 sequence, is closely related, and the African haplogroup is also present, albeit at low frequencies, in Southwest Asia. Studies of ancient mitochondrial DNA from Africa and Southwest Asia may further clarify the issue. It also is possible that North African aurochs may have substantially contributed to the genetic pool of contemporary African cattle through male introgression (Pérez-Pardal et al. 2010).

A preponderance of zooarchaeologists, including the analyst with first-hand experience with the specimens (Gautier 1984; Gautier 1987), have come to doubt the strength of the osteological evidence for 10,000-year-old domestic cattle in Egypt's Western Desert (e.g. Wendorf and Schild 1998). Uncontroversial dates for domestic Bos in the Nabta-Kiseiba area are c. 5750-4550 BC, and are not associated with caprines there until a few centuries later (Gautier 1984). Honegger (2005, p. 247) reports two 'Neolithic' sites, south of the Nile's Second Cataract and east of the locale of the later Kerma civilization, that have yielded remains of domestic cattle with an associated date of c. 7000 BC. Geographic proximity of these Nubian occurrences to the Nabta-Kiseiba region suggests domestic cattle appeared first in the grassy hinterlands of the Nile in this region, as dates for cattle remains are oldest in the eastern Sahara-Sahel and youngest in the far western Sahara.

It is clear from skeletal evidence, Saharan rock art, and Dynastic Egyptian representations that Africa's oldest cattle were straight-backed and had lyre-shaped horns. Saharan rock art depicts calves tied up to picket lines at a settlement as cows with full udders are brought in, which may reflect early milking practices that continue in Africa into the present day. Tishkoff et al. (2007) have investigated the genetic basis of lactase persistence in East African populations, finding that, in place of the Eurasian mutation, three mutations facilitating lactase persistence exist in different populations. They note the $\mathrm{C}-14010$ allele 
for lactase persistence is high in speakers of Nilo-Saharan languages, which span an area from the central Sahara and Lake Chad basin, into central and eastern Africa. A rough estimate of the age of this mutation places it 6,000-7,000 years ago, 95\% c.i. 2,000-16,000 years (Tishkoff et al. 2007, p. 198), hinting at the emergence of such a co-evolutionary trajectory in the early stages of cattle domestication. This inference of an early and independent 'secondary products' economy is rendered more plausible by what is now known of the early appearance of dairying in Eurasia (Evershed et al. 2008; Ingram et al. 2009; Itan et al. 2009; see also Linseele 2010).

As the final desiccation of the Sahara set in about $2500 \mathrm{BC}$, pastoralists gradually abandoned the Saharan region, shifting southward with the Sahelian biome most suitable for their herds. Some herders were able to maintain their way of life in environments similar to those previously typical of the Sahara for a few more millennia in places like the Chad basin (Breunig et al. 1996). However, other herders entered areas that exposed their herds to new disease challenges.

In the more closed habitats of western Africa, the endemic tsetse fly transmits trypanosomes to hoofed animals. Indigenous wild bovids are trypanotolerant, the result of their long co-evolution with the infection, but domestic livestock develop acute symptoms that often result in death. Not all infected animals die, but trypanosomes persist in recovered, asymptomatic animals, and may resurge if helminthic infestations, low plane of nutrition, or late stages of pregnancy cause loss of condition.

Tsetse is present in bushier habitats of Central and East African savannas, which can be avoided or modified by herders who understand the link between tsetse bites and sleeping sickness in their herds. However, cattle foraging in East African savannas risk theileriosis, or East Coast Fever (ECF), caused by the protozoan parasite Theileria parva parva and transmitted from host to host by ticks. Theileriosis kills nearly a half million cattle yearly, with mortality as high as $90 \%$ in herds first exposed to ECF (Lawrence et al. 1994a, b). A live vaccine associated with an infection treatment exists (Radley et al. 1975), however, it is not yet easily accessible to the pastoral communities. Immunization and tick control measures are insufficient to prevent losses of 13-20\% of the annual calf crop due to ECF (Kambarage 1995; Mulei et al. 1995; De Castro et al. 1997).

The original route for infection of cattle with Theileria parva was probably from African buffalo, Syncerus caffer, as pastoralists moved their herds into eastern Africa and zones of theileriosis for the first time (Gifford-Gonzalez 2000). T. p. parva is one of two subspecies; the other, T. parva lawrencei, is the infectious agent for Corridor Disease (CD) in African buffalo (Lawrence et al. 1994a). Like ECF, CD is transmitted from host to host by ticks. In buffalo-to-buffalo infections, $T$. p. lawrencei produces few clinical symptoms, typical of long co-evolved parasites. However, CD infection in cattle manifests similarly to $\mathrm{ECF}$, as an acute and usually fatal disease.

Modern breeds reflect adaptations to local environmental conditions and cultural valuations. In the Sahel, the Fulani-Sudanese cattle breed is humped, but with classic lyreshaped horns as depicted in prehistoric Saharan rock art. They are used as dairy cattle and beasts of burden, tolerating drier habitats well. The non-humped Kuri breed of the Lake Chad basin, though resembling Fulani cattle in build and dairy use, is not very heattolerant, and the breed reportedly wallows daily to regulate body temperature (Porter and Mason 2002). Kuri have been bred for large, inflated horns, which grow in lyre or crescent shape. Unlike the straight-backed breeds of West African closed habitats, these breeds do not display appreciable trypanotolerance (Tawah et al. 1997).

Certain breeds, including the N'Dama, Baoulé, Somba, and other West African shorthorns, are renowned for their ability to live in tsetse-infested zones. All are small, 
straight-backed breeds that do not actually resist infection but rather survive and reproduce with moderate disease loads (Roberts and Gray 1973a, b).

The genetics of trypanotolerance in cattle has been intensively explored (e.g. Hanotte et al. 2003). It is under complex genetic control involving several genes and gene networks with responses to parasitaemia and to anaemia-a major consequence of trypanosomiasis infection-under distinct genetic controls. Both taurine and indicine genetic factors contribute to trypanotolerance in crossbred populations, suggesting that at least some general mechanism of tolerance to blood parasite infection exists among tropical domestic bovines.

When the size diminution typical of trypanotolerant breeds began, or even whether it was initially an adaptation to sleeping sickness, remains an open question. Because size diminution occurs in wild and domestic animals subject to a variety of stresses, and not only trypanosomal infection, it is best to refrain from assuming a causal link here. Manning (2008) reports that most cattle in 2200 and 2400 BC settlements along the lower Tilemsi Valley, a tributary to the Niger River, are similar in size to N'Dama and West African dwarf shorthorns. However, she notes the presence of a few very large animals in her sample, and interprets this variation as off-take from a mix of cattle-keeping strategies, such as local farmers versus savanna pastoralists. The Adrar Bous cow from Niger, restudied by Gifford-Gonzalez and re-dated to $2868-2833$ cal BC, is a similarly small female, likewise within a more variable sample of sizes (Clark et al. 2008).

With regard to East Coast Fever, Central and East African cattle breeds display higher tolerance of Theileria than do imported breeds. Because the intensity of ECF infection is determined by total tick load, inhibition of tick blood meal episodes by behavioral and immunological responses produces lower rates of infection (Medley et al. 1993; Waladde et al. 1993). Probably through draconian natural selection, indigenous African cattle breeds have evolved higher resistance to ECF, through both tick-resistance and Theileria tolerance. Ankole cattle of Central Africa, a straight-backed breed with huge horns, have strong resistance to tick infestation and higher productivity in the face of Theileria infection (Ocaido et al. 1996). Ankole cattle are not trypanotolerant, indicating this disease was not a challenge in environments in which they evolved.

East African Boran cattle, a humped breed reflecting indicine introgression, display high resistance to heat and ticks and good productivity on poor forage and low amounts of water, compared to foreign breeds (Porter and Mason 2002). While they generally display poor response to trypanosomal infection, the Orma Boran, herded in tsetse regions near the Indian Ocean coast, display some trypanotolerance (Dolan 1998), suggesting that selection can situationally favor stronger expression of this trait. Humped Sanga cross-breeds of southern Africa such as the Nguni, Tuli, and Afrikander carry as little as one-sixth of the tick load of European cattle breeds stocked on the same pasturage, and show higher successful calving rates (Porter and Mason 2002; Spickett 1994).

Genetic research on modern African cattle populations has clarified the history of Bos on the continent, including the introgression of indicine $Y$-chromosome heritage (Hanotte et al. 2000, 2002). Their principal components analysis of 15 microsatellites is consistent with taurine African cattle from the eastern Saharan region dispersing into West Africa, where some evolved as trypanotolerant taurine cattle, and it indicates dispersion south to the Great Lakes of the Western Rift, and into East Africa and Southern Africa. Genetic evidence also indicates that the Horn of Africa was the original entry point of humped, or zebu, cattle into the African continent with two, and maybe more, separate introductions and movement of indicine genes into the continent. Mitochondrial and $Y$-chromosome analysis shows that South Asian zebu bulls crossbred with African taurine cows, producing the so-called sanga cattle breeds, earliest in East Africa, then north, west, and south. 


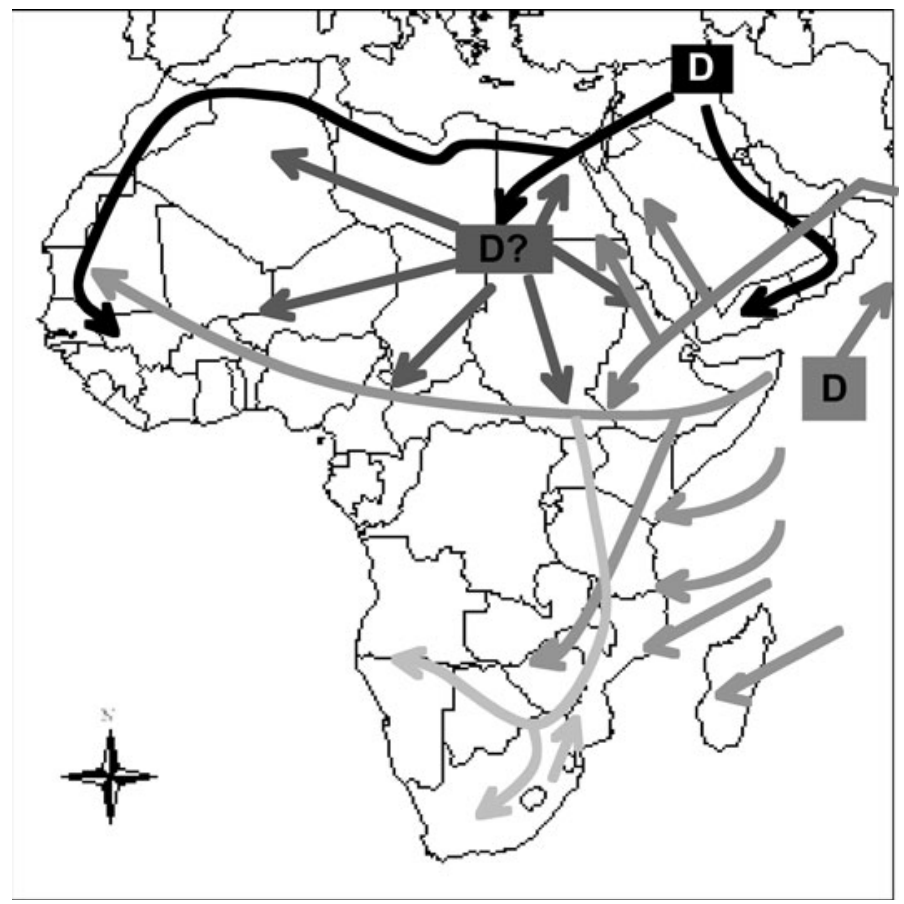

Fig. 1 Cattle: two major exogenous centers of cattle domestication, Southwest Asia and the north of the Indian subcontinent, manifest in the genetics of African cattle. An independent domestication on the continent is at present neither proved nor disproved. The earliest domestic African cattle were humpless and of the taurine type (black and/or darkest gray arrows), while two distinct zebu influences, one probably overland and another, later via the Indian Ocean trade are evident in the DNA of African cattle (lighter gray arrows). Central and south African sanga cattle are an ancient, admixed population between zebu and taurine (lightest gray)

Genetic calibration suggests that this was well underway before the entry of the Portuguese into the Indian Ocean trade.

The earliest non-controversial archaeological evidence for humped zebu cattle in Africa are rock paintings of cattle and camels in the Horn of Africa, dated around the mid-1st millennium $\mathrm{AD}$, according well with the genetically derived estimate. Sanga cattle reached southern Africa in the late 1st millennium AD, presumably traveling overland with Bantuspeaking agro-pastoralists. However, a direct introduction of breeding stock from the Indian Ocean trade into southern Africa remains a possibility. The most recent introgression and dispersion of male-mediated zebu genes in African cattle genetics is likely linked with the devastating late nineteenth to early twentieth century rinderpest epidemics, which decimated indigenous cattle stocks from Sudan to South Africa, with zebu cattle more tolerant to rinderpest than taurine animals (Rossiter 1994).

Goats

Many breeds of goats, Capra hircus, are recognized in Africa, all being descended from non-native members of the wild bezoar goat, Capra aegagrus. Domestic goats of the world display at least six distinct mtDNA lines (Luikart et al. 2001), possibly reflecting multiple 
domestication events. Among the most notable aspects of the distribution of these variants is that, unlike cattle, goats display little geographic patterning in the expression of the haplogroups. Luikart et al. (2001) interpret this lack of phylogeographic patterning as reflecting the continual transport of goats through human commerce over their entire history as domesticates. However, more recently, Naderi et al. (2008) noted that such diversity of mitochondrial DNA haplogroups is also compatible with a single domestication center, with a phase of human management of wild or semi-domesticated goat populations comprising multiple mtDNA lineages, before geographic dispersion and subsequently local extinction of some haplogroups (Fernández et al. 2006).

$Y$-chromosome haplotypes from 20 living populations indicate a common origin for goat patrilines in the Levant and Maghrebian coastal regions (Pereira et al. 2009). The authors argue that it is the result of maritime trading, with dispersal of male goats from Southwest Asia along the North African coast overlaid with multiple commercial exchanges. This accords with Hassan's (2000) prediction that caprines were introduced from Southwest Asia c. 5000 BC by two routes, one along the Mediterranean coast, where they appear earlier than cattle in sites, and the other via the Red Sea Hills region of the Egyptian Red Sea coast, based on evidences from Sodmein Cave (Hassan 2000; Newman 1995). Archaeologically, caprines appear earlier than cattle in the Late Khartoum tradition of the Sudanese Nile, where they were integrated into a fishing and gathering-intensive way of life by the late 6th to early 5th millennia BC. A third route of entry for caprines into the Nile Valley would be overland via the Sinai Peninsula and Nile Delta regions, but so far this dates to later than their first appearances elsewhere in northeastern Africa (Wetterstrom 1993).

African goats remain poorly studied at the molecular level. However, work so far using mitochondrial and microsatellite DNA indicates a lack of phylogeographic structure amongst them (Chenyambuga et al. 2004; Tesfaye 2004), while microsatellite loci provide evidence for a geographic pattern of Sahelian goat introgression within West African Dwarf goat (Hoeven et al. 2007). Luikart et al. (2006) argued that genetic markers suggest that goats did not enter sub-Saharan Africa until about $1000 \mathrm{BC}$, which timing would roughly coincide with the final Saharan desiccation. However, Carter and Flight (1972) report a dwarf goat from Ntereso and Kimtampo, Ghana, in the 2nd millennium BC.

In any case, African goats' phenotypes reflect substantial adaptation to local conditions. The Sahelian and Sudanian breeds are light-colored, long limbed, and heat tolerant, and Somali goats of arid eastern Africa are also predominantly light-colored, though with different ear form and body build (Porter and Mason 2002). By contrast, breeds associated with closed habitats of western Africa display size reduction. The West African Dwarf, or 'forest goat' (known as the 'pygmy goat' to modern fanciers) is widespread in closed habitats, possessing short legs, a high reproductive rate, and trypanotolerance (Porter and Mason 2002). Another breed, the Nigerian Dwarf, may have a distinct origin, because it displays an overall reduction in body size, rather than only shortened legs. This, too, is a very prolific breed, reproducing multiple times a year (Porter and Mason 2002). The South African Boer breed, although 'improved' by crossing with Angora and other foreign goat stocks, is also a stocky goat with high reproductive rates and the ability to thrive on poor forage (Porter and Mason 2002). Goats also vigorously defend themselves against tsetse bites, sharply curtailing the number of blood meals by which trypanosomal infection is transmitted. Experiments have shown that the ratio of feeding attempts to successful blood meals is 63:1 in goats, versus 4:1 in cattle (Connor 1994, p. 177).

Goats are browsers and are used by modern pastoralists as 'shock troops' for clearing brushy tsetse zones of sub-Saharan Africa. Lamprey and Waller (1990) document Purko 
Maasai using both controlled burning and seasonal introduction of goats to reduce brushy habitats in the Mara region of southwestern Kenya in the early twentieth century, after they were displaced by the British to this cattle-hostile zone.

\section{Sheep}

Sheep Ovis aries are most likely descended from varieties of the Asiatic mouflon Ovis orientalis (Bruford and Townsend 2006). Research on mtDNA has initially found two distinct and common haplogroups, named A and B (Hiendleder et al. 1998; Wood and Phua 1996), suggesting more than one domestication event. Subsequently, at least three more, less common lineages have been identified (Meadows et al. 2007) (Figs. 1, 2). Haplogroup A is the most widespread worldwide. All sampled eastern and southern African sheep are haplogroup A (Bruford and Townsend 2006), despite a much more diverse representation of haplogroups $\mathrm{A}$ and $\mathrm{B}$ in the nearby Arabian Peninsula. $Y$-chromosome research identifies two separate lineages in haplogroup A, including in African sheep (Meadows et al. 2007). However, no clear phylogeographic signal is observed, possibly the result of the restricted number of African breeds so far analysed.

African sheep are of two varieties, thin-tailed and fat-tailed or fat-rumped. Thin-tailed sheep are today found predominantly from Western Africa to Sudan, and the fat-tailed sheep are found in Eastern and Southern Africa. Recent research on microsatellite loci (Muigai 2003) indicates that these two types of sheep are reflected in two distinct genetic groups amongst sub-Saharan African sheep. This genetic evidence concurs with archaeological evidence for two geographically distinct entry points of domestic sheep on the sub-Saharan African continent, namely Egypt for the thin-tailed and the Horn of Africa for the fat-tailed. North African populations of either type may be 'carpet wool' breeds, producing coarse wool (Porter and Mason 2002), whereas sub-Saharan sheep of each type are hair breeds, having smooth coats. Rock art from Ethiopia to South Africa represents fat-tailed sheep, probably reflecting the value of their fat deposits as a vital nutrient for farmers and pastoralists, whose traditional diet was low in dietary fats.

Sheep were present at Merimda Beni Salama, Egypt by 4100 BC, probably entering the Nile Delta region overland from the Levant (Gautier 2002). Thin-tailed sheep are depicted in Early Dynastic Egyptian tomb paintings (3100-2613 BC), whilst fat-tailed sheep are depicted during the Middle Kingdom, 1991-633 BC (Clutton-Brock 1993). This suggests the earliest African sheep were likely thin-tailed varieties. Sheep are the earliest securely dated domesticate in southern Africa, appearing in the late first millennium BC (Sealy and Yates 1994; 1996). By the time of Portuguese and Dutch contact with Khoisan speakers of the Cape in the fifteenth century, goats and cattle were in indigenous herds as well (Smith 2008).

Modern African sheep breeds are diverse not only in tail form and coat type but also in horn form and other attributes. The Sahel-type sheep is a lop-eared, thin-tailed hair sheep distributed in drier regions from Mauritania to Chad. Males have corkscrew-type horns (Porter and Mason 2002), resembling those portrayed in Early Dynastic Egyptian art. The West African Dwarf occupies humid tropical habitats from West to Central Africa, and is a thin-tailed hair sheep, small and trypanotolerant. Males have curved horns and a throat ruff or mane, thus diverging from the Sahel-type. Compared to the dwarf goats of the same region, this breed's growth rate is slow and offspring mortality is higher (Porter and Mason 2002), possibly resulting from sheep's greater overall vulnerability to trypanosomiasis (viz. Connor 1994). Whether this reflects a more recent arrival in closed West African habitats than that of goats will depend upon further archaeological evidence. 


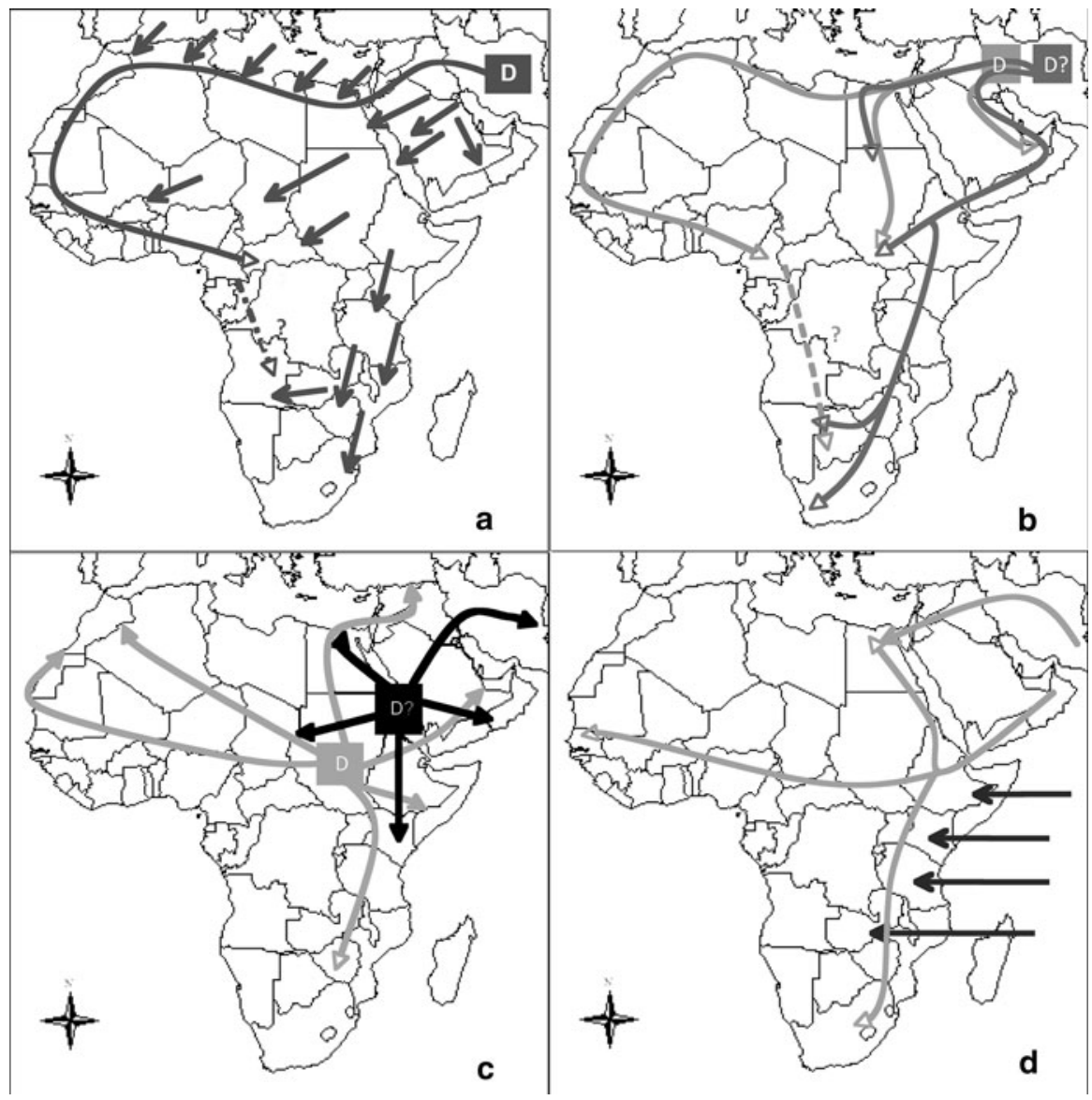

Fig. 2 Speculative maps of dispersal of goats, sheep, donkey, and chicken in Africa. a Goat: archaeological information supports three main entry points: the Mediterranean coast; the Red Sea Hills; and overland via the Sinai Peninsula and Nile Delta on the African continent from the Southwest Asian domestication center (D). b Sheep: archaeological and molecular genetic information supports two separate introductions of sheep on the continent, the thin-tailed sheep (lighter line) and the fat-tailed sheep (darker line), with two main entry points for the latter. The movement of sheep across the Congo Basin remains speculative. Whether or not the fat-tailed sheep was domesticated separately is presently unknown. c Donkey: the species was certainly domesticated within the African continent with a second domestication centre within or outside the African continent within the Arabian Peninsula. d Chicken: two main waves of introduction of domestic chicken to Africa from centers of domestication in Asia are likely. Chickens were introduced along the East African Coast (dark lines), and an overland route brought chickens to the Horn of Africa (light lines) with subsequent dispersion inland. An entry point through Egypt is also possible

\section{Dromedary Camels}

The dromedary or one-humped camel, Camelus dromedarius, was likely domesticated from wild ancestors in the Arabian Peninsula, where no wild representatives survive today (Grigson 1983; Grigson et al. 1989). Its superior ability to forage in semi-deserts with farflung water sources and to endure treks across true desert enabled Africans to exploit more fully expanding arid zones. Radiocarbon dates so far suggest a very recent emergence of 
camel-based pastoralism in Africa. Rowley-Conwy (1988) reports camel dung from the Predynastic Napatan site of Qsar Ibrim in the early first millennium BC, but the species is not ubiquitous in the Nile Valley until a thousand years later. Dromedaries dated to 1300-1600 AD were found at Laga Oda, in the Horn of Africa (Clark and Williams 1978). The genetics of the species in sub-Saharan Africa remains poorly studied, with the exception of Kenya (Mburu et al. 2003).

Pigs

Domestic pigs are present throughout the African continent, although their geographic distribution is intermittent in comparison to other livestock species, likely reflecting cultural and religious practices. The ancestral wild boar Sus scrofa has a Eurasian and North African distribution, and, not surprisingly, mtDNA reveals at least six domestication independent events across the range of the wild ancestor (Giuffra et al. 2000; Larson et al. 2005). Pigs were important food animals in pre-Islamic Berber speaking parts of the Maghreb 4000-1000 BC, and in Dynastic Egypt until the advent of Islam (Blench 2000). No aDNA work has established the relation of these ancient suids to wild North African or wild and domestic Southwest Asian pigs.

A few present-day African pig populations have been included in a recent large geographic scale study of mitochondrial, $Y$-chromosome and microsatellite polymorphism of suids (Ramírez et al. 2009). The results indicate that domestic pig populations in Benin and Nigeria are of European origin, although a North African origin cannot be completely excluded, given the similarity of the genetic signature of European and North African wild boar. These breeds may date to introductions during Portuguese exploration in the fifteenth century.

However, the situation is more intriguing for populations in western Kenya and Zimbabwe, where animals display both European and Far Eastern mitochondrial DNA haplotypes (Ramírez et al. 2009). At first glance, these might have been introduced through European $\times$ Asian crossbreeds brought in during the colonial period, as British breeds were strongly admixed with Chinese pigs in the eighteenth to nineteenth centuries (Porter 1993). However, Kenyan and Zimbabwean Mukota pigs display high frequencies of a $Y$-chromosome haplotype absent from the European-Asian crossbreeds, suggesting that these breeds were directly introduced from Southeast or East Asia. Blench (2000) has suggested that these breeds might have been introduced directly from the Macau region into Africa by the Portuguese. However, whether or not the arrival of Asian pigs predates the European exploration of the eastern coast of the African continent is as yet unresolved. In any case, archaeologists are advised that it is premature to assume all pig remains in East Africa ipso facto derive from the colonial period, and to seek direct dates and aDNA analysis of such finds.

\section{Donkeys}

Molecular genetics has clarified a long debate over the maternal origins of the domestic donkey, Equus asinus. Subspecific forms of its ancestor, Equus africanus, were found across arid zones of Africa and the Arabian peninsula, and it was therefore moot whether donkeys were domesticated in Africa or the Near East, as well as whether Asiatic wild equines such as the kiang and kulan contributed to donkey ancestry. Analysis of wild and domestic mtDNA sequences of the species and its close relatives from 52 countries identified two maternal lineages within domestic donkey (Beja-Pereira et al. 2004). 
The 'Nubian lineage' was undoubtedly domesticated in Africa, as indicated by its close relationship with the Nubian African wild ass sequences (E. africanus africanus). The ancestral population and the region of domestication of the second lineage, the Somali lineage, is less clear given the past presence of wild ass also within the Arabian Peninsula. The study also excluded Asiatic wild equines as progenitors. A more recent analysis by Kimura et al. (2010) indicates the presence of another, now-extinct mtDNA lineage in archaeological specimens and continues to support conclusions on domestication of the Nubian wild asses.

The domestic donkey is found in Dynastic Egypt and Southwest Asia around 2500 BC, but early Dynastic donkey burials at Abydos date closer to 3045 BC (Rossel et al. 2008). One domestic donkey element is reported from the upper level of a cave deposit at Jebel Shaqdud, a Sudanese Neolithic site (Peters 1991), which dates around 1950 BC, and from royal burials at Kerma in Nubia, 2000-1559 BC. In East Africa, sparse remains of donkey were recovered from Narosura (Gramly 1972).

\section{Cats}

Because of its ubiquity in later Dynastic Egyptian art and mortuary practices, the domestic cat Felis catus was long considered to have been domesticated in Egypt from $F$. silvestris libyca (e.g. Malek 1997). Linseele et al. (2007) reported on probable taming of a cat found buried in a Predynastic cemetery at Hierakonpolis, dated to c. 3700 BC, originally attributing this to Felis silvestris. The specimen displays healed fractures of the left humerus and right femur, reflecting a period of protection after the breaks of these bones, which the authors interpret as evidence for taming, which finding still stands, despite their later re-identification of the species as $F$. chaus, which is not ancestral to domestic cats (Linseele et al. 2008).

Archaeological and genetic evidence implies a geographically broader and substantially older origin for domestication of the wild cat. Scattered finds of cat bones on Cyprus in the PPNB reflect human introduction of non-native Felis silvestris into the island's ecosystem. A 7500 BC joint burial of a human and a juvenile cat in the Neolithic village of Shillourokambos has been interpreted by Vigne et al. (2004) as evidence for taming of the species there. Linseele et al. (2007) question whether the evidence supports the inference of taming in the latter case. Whether other cats recovered from similar Predynastic contexts are domestic awaits better documentation of context and ancient DNA analysis.

A large-scale mtDNA analyses of many cat species on three continents (O'Brien et al. 2008) supports the idea that cats were domesticated throughout a broad range of Southwest Asia. All domestic cats bear Clade IV mtDNA haplotypes of the $F$. silvestris libyca subspecies, the geographic range of which includes Africa and Southwest Asia. O'Brien et al. (2008, p. 274) state that, 'a STRUCTURE-based population genetic analysis identified a discrete population of wildcats from the Near East (Israel, United Arab Emirates and Saudi Arabia...) that probably reflects the ancestral founder population for the world's domestic cats.' The study found that extant domestic cats comprise at least five mtDNA lineages, each of considerably greater antiquity ( $>100,000$ years) than the hypothesized inception of domestication, suggesting multiple domestication events across the species' geographic range. Since wild cats were probably attracted to many settlements where rodents and small birds parasitized on stored grains on multiple occasions, several taming and domestication processes are possible. Driscoll et al. (2009) argue that cats may have to some extent self-domesticated, as individuals able to tolerate proximity to people and their 
activities exploited the pest-rich niche of human settlements, where they found mates among conspecifics with similar tolerances.

Dogs

The dog Canis familiaris is the oldest and most phenotypically diverse domestic mammal, with earliest archaeological finds dating to the late Pleistocene, perhaps as early as 30,000 BP in Eurasia (e.g. Dayan 1994; Germonpré et al. 2009). Geneticists have debated how to interpret the great genetic diversity of dogs throughout the world, in terms of their history as a distinct lineage and their region of domestication (e.g. Savolainen et al. 2002; Vilà et al. 1997; Wayne et al. 2006; Wayne and Ostrander 2007). However, some basic facts are clear: all domestic dogs, including indigenous dogs in the Americas, are descended from the Eurasian gray wolf Canis lupus. In a recent large-scale study of mitochondrial DNA, Pang et al. (2009) provided data that all 10 haplotypic groups in domestic dogs originate in Southern China; they estimate this event as less than 14,300 BC, with at least 51 maternal contributors. How this genetic evidence relates to the above-mentioned Palaeolithic doglike cranial evidence is presently moot. One possibility is that the early finds represent lines that did not survive as ancestors of Holocene dogs, whilst the East Asian domestication did produce many surviving material lineages.

The history of African domestic dogs has been neglected, due partly perhaps to the rarity of their remains in archaeological deposits, and partly perhaps to researchers' assumptions about their 'mongrelisation' in colonial times. Dogs have considerable economic importance and status among groups who hunt (Lupo n.d.), and evidence from the Nile Valley testifies to their status in early complex societies there. A late first millennium $\mathrm{BC}$ joint burial of a dog and a forager is reported at Cape St. Francis, Eastern Cape, South Africa (Mitchell 2002). Chaix (1999) reports on interred dogs in the mortuary complex at Kerma, 2700-1500 BC, which were uniformly taller and more robust than those interred in Dynastic Egyptian sites. Chaix interprets them as shepherd dogs of a distinct local breed.

Modern DNA research on African dogs is just beginning but has produced fascinating results. Boyko et al. (2009) sampled microsatellites and SNPs from village dogs from Egypt to Namibia and pure bred dogs of putative African origin. They found that African village dogs display high genetic diversity and are remarkably free from admixture with non-African breeds, except in two exceptional situations of deliberate breeding. Several breeds thought to be Africa-derived, such as Afghan hounds/salukis on the one hand and basenjis on the other, cluster genetically with village dogs from Egypt and the Congo basin, respectively. However, Rhodesian Ridgeback and Pharaoh Hound breeds show predominantly non-African genetic makeup.

\section{Chickens}

The red jungle fowl, Gallus gallus, the wild ancestor of the domestic chicken, has five subspecies from India to southern China. Genetic analysis of modern populations is bringing forward new information on the pattern of chicken domestication, which previously tended to follow the domestication-as-invention model and presume the singularity of the process. More particularly, Liu et al. (2006) revealed seven mtDNA haplogoups or clades within domestic chickens, suggesting multiple domestication events across the G. gallus subspecies' geographic range. Moreover, the domestic chicken's yellow leg skin phenotype has been shown to originate from an introgression by the grey junglefowl, 
G. sonnerati, indicating that more than one Gallus species has contributed to the genetic pool of at least some of the domestic breeds (Eriksson et al. 2008).

Chickens are more efficient converters of forage into body mass than are ruminants, which require 7-8 kg of forage to gain $1 \mathrm{~kg}$ of body weight, while the ratio for chickens is 2.2-2.6:1 kg. Pasture-foraging chickens, the closest modern equivalent to the free-ranging chickens of traditional farms, have the lowest conversion ratio (Seipel et al. 2004; Taha 2003). If chickens are used for their eggs rather than their flesh, their energy needs are about one third of those for meat production (Taha 2003). Hens lay eggs in a nest until they reach a clutch of 10-12 eggs (Damerow 1995), and if humans remove their eggs, they will lay more to reach the optimal clutch size. Their rapid adoption into farming systems across the world, especially for egg production, is thus quite understandable.

Recent sequencing information from the mitochondrial D-loop of African village chickens is providing new insights into the origin and diversity of domestic chickens on the continent (Muchadeyi et al. 2008; Razafindraibe et al. 2008; Adebambo et al. 2010; Mwacharo et al. 2010). They indicate the presence of a least two ancient mtDNA haplogroups in East Africa (Muchadeyi et al. 2008; Razafindraibe et al. 2008; Mwacharo et al. 2010), while only one major haplogroup is observed in West Africa, specifically Nigeria (Adebambo et al. 2010). The origin, timing and entry points of these lineages remain uncertain. Data so far suggest that the commonest haplogroup throughout the continent may originate from the Indian subcontinent and have entered via an overland route. The second commonest haplogroup, detected so far in eastern and southern Africa only, is probably of Southeast Asian origin and could have reached Africa via the Indian Ocean maritime trade. Interestingly, Mwacharo et al. (2010) also detect a third haplogroup in East Africa, although at low frequency, absent in commercial chickens, indicating that the history of Gallus gallus in Africa may be even more complex. Large-scale geographic studies of both African and Asian chickens could further clarify the history of African chickens.

Archaeological evidence from Mali (MacDonald 1992), Nubia (MacDonald and Edwards 1993), the Swahili Coast (Mudida and Horton 1996), and southeastern Africa (Plug 1996) all indicate that chickens entered the continent in the first millennium AD, a time of intense overland and maritime trade between Asia and Africa. They are present rarely in Egyptian New Kingdom (1425-1123 BC) art, and not common until Ptolemaic times (Blench and MacDonald 2000). MacDonald (1992) notes that early Inland Niger Delta chickens are 'diminutive,' perhaps reflecting another case of dwarfing.

\section{Guinea Fowl}

The domestic guinea fowl, Numida meleagris, is an African domesticate that spread to other continents in historic times. They are used for meat and eggs, and serve as guards at farmsteads, when disturbances set off their loud calls. In the first millennium AD, Sahelian guinea fowl came to share settlements with chickens and in many regions were largely supplanted by them. They are probably a behaviorally marginal species for domestication, or one with a trajectory toward domestication interrupted by introduction of the more productive chicken. MacDonald (1992, p. 307) notes that guinea fowl are more likely than chickens to go feral, and all guides to their husbandry discuss the challenge of their habit of laying eggs away from human habitations. African people keeping guinea fowl today may gather wild guinea fowl eggs and place them under sitting chickens, which tend to them once hatched, thus introducing a constant flow of wild genes into already behaviorally problematic captive populations. 
However, despite their frailties as domestic poultry, guinea fowl remove ticks from livestock and human settlements, as well as hunt snakes, and such behaviors may have made them desirable to livestock owners. Wild Numida meleagris consume ticks in considerable quantity in Africa (Angus and Wilson 1964; Grafton 1971; Skead 1962), and they have proved effective in reducing deer ticks in controlled trials on Long Island, New York (Duffy et al. 1992). It may be that guinea fowls, similarly to cats, invited themselves into human settlements as commensals because of high concentrations of favored foods and were tolerated and gradually domesticated by humans.

\section{Conclusion}

African domesticates, whether or not from foreign ancestors, have adapted to disease and forage challenges throughout their ranges, reflecting local selective pressures under human management. Adaptations include dwarfing and an associated increase in fecundity, tick resistance, and resistance to the most deleterious effects of several mortal infectious diseases. While the genetics of these traits are not yet fully explored, they reflect the animal side of the close co-evolution between humans and domestic animals in Africa. To fixate upon whether or not cattle were independently domesticated from wild African ancestors, or to dismiss chickens' swift spread through diverse African environments because they were of Asian origin, ignores the more relevant question of how domestic species adapted to the demands of African environments, and how African people integrated them into their lives. Such knowledge is especially vital in a time of climate change and in the face of introductions of many new genetic stocks by well-intentioned, but not always well-advised, development initiatives. For archaeologists, it is important to understand that the texture supplied by genetic analysis does not supplant our archaeological narratives but rather raises new questions about human agency and culture contact that can only be investigated with well-articulated archaeological research.

Acknowledgments The authors wish to thank the anonymous reviewers of this paper for their sharp-eyed and very helpful comments. We appreciate as well the many shared articles and research reports from colleagues too numerous to list here.

Open Access This article is distributed under the terms of the Creative Commons Attribution Noncommercial License which permits any noncommercial use, distribution, and reproduction in any medium, provided the original author(s) and source are credited.

\section{References}

Adebambo, A. O., Mobegi, V. A., Mwacharo, J. M., Oladejo, B. M., Adewale, R. A., Ilori, L. O., et al. (2010). Lack of phylogeographic structure in Nigerian village chickens revealed by mitochondrial DNA D-loop sequence analysis. International Journal of Poultry Science, 9, 503-507.

Albarella, U., Dobney, K., \& Rowley-Conwy, P. (2006). The domestication of the pig (Sus scrofa): New challenges and approaches. In M. A. Zeder, D. G. Bradley, E. Emshwiller, \& B. D. Smith (Eds.), Documenting domestication: New genetic and archaeological paradigms (pp. 209-227). Berkeley: University of California Press.

Angus, A., \& Wilson, K. J. (1964). Observations on the diet of some game birds and Columbidae in Northern Rhodesia. 1. The Helmeted Guineafowl (Numida meleagris). Puku, 2, 1-9.

Balasse, M., \& Ambrose, S. H. (2005). Distinguishing sheep and goats using dental morphology and stable carbon isotopes in C4 grassland environments. Journal of Archaeological Science, 32, 691-702. 
Beja-Pereira, A., England, P. R., Ferrand, N., Jordan, S., Bakhiet, A. O., Abdalla, M. A., et al. (2004). African origins of the domestic donkey. Science, 304, 1781.

Blench, R. (2000). A history of pigs in Africa. In R. M. Blench \& K. C. MacDonald (Eds.), The origins and development of African Livestock: Archaeology, genetics, linguistics, and ethnography (pp. 355-367). London: Routledge.

Blench, R., \& MacDonald, K. C. (2000). II.G.6 Chickens. In K. F. Kiple \& K. C. Ornelas (Eds.), The Cambridge world history of food (pp. 496-499). Cambridge: Cambridge University Press.

Boyko, A. R., Boyko, R. H., Boyko, C. M., Parker, H. G., Castelhano, M., Corey, L. et al. (2009). Complex population structure in African village dogs and its implications for inferring dog domestication history. Proceedings of the National Academy of Sciences, 13903-13908.

Bradley, D. G., \& Loftus, R. (2000). Two Eves for taurus? Bovine mitochondrial DNA and African cattle domestication. In R. M. Blench \& K. C. MacDonald (Eds.), The Origins and Development of African Livestock: Archaeology, genetics, linguistics, and ethnography (pp. 244-258). London: UCL Press.

Bradley, D. G., MacHugh, D. E., Cunningham, P., \& Loftus, R. T. (1996). Mitochondrial diversity and the origins of African and European cattle. Proceedings of the National Academy of Sciences, USA, 93, 5131-5135.

Breunig, P., Neumann, K., \& Van Neer, W. (1996). New research on the Holocene settlement and environment of the Chad basin in Nigeria. African Archaeological Review, 13, 111-145.

Bruford, M. W., \& Townsend, S. J. (2006). Mitochondridal DNA diversity in modern sheep. In M. A. Zeder, D. G. Bradley, E. Emshwiller, \& B. D. Smith (Eds.), Documenting domestication: New genetic and archaeological paradigms (pp. 306-316). Berkeley: University of California Press.

Carter, P. L., \& Flight, C. (1972). Report on the fauna from the sites of Ntereso and Kintampo Rock Shelter 6 in Ghana, with evidence for the practice of animal husbandry in the second millennium BC. Man n.s., 7, 277-282.

Chaix, L. (1999). The dogs from Kerma (Sudan) 2700 to 1500 BC. In C. Becker, H. Manhart, J. Peters, \& J. Schibler (Eds.), Historia Animalium ex Ossibus (pp. 109-126). Rahden: Verlag Marie Leidorf.

Chenyambuga, S. W., Hanotte, O., Hirbo, J., Watts, P. C., Kemp, S. J., Kifaro et al. (2004). Genetic characterization of indigenous goats of sub-Saharan Africa using microsatellite DNA markers. AsianAustralian Journal of Animal Science, 17, 445-452.

Clark, J. D., Carter, P. L., Gifford-Gonzalez, D., \& Smith, A. B. (2008). The Adrar Bous cow and African cattle. In J. D. Clark \& D. Gifford-Gonzalez (Eds.), Adrar Bous: Archaeology of a Central Saharan Granitic ring complex in Niger (pp. 355-368). Tervuren: Musée Royal de l'Afrique Centrale.

Clark, J. D., \& Williams, M. A. J. (1978). Recent archaeological research in southwestern Ethiopia (1974-1975). Annales d'Éthiopie, 11, 19-44.

Clutton-Brock, J. (1993). The spread of domestic animals in Africa. In T. Shaw, P. Sinclair, B. Andah, \& A. Okpoko (Eds.), The archaeology of Africa: Foods, metals, and towns (pp. 43-60). London: Routledge.

Connor, R. J. (1994). African animal trypanosomiases. In J. A. W. Coetzer, G. R. Thomson, R. C. Tustun, \& N. P. J. Kriek (Eds.), Infectious diseases of livestock with special reference to Southern Africa. Volume 1 (pp. 167-205). New York: Oxford University Press.

Damerow, G. (1995). Storey's guide to raising chickens: Care, feeding, facilities. Storey Publishing, Pownal, VT.

Dayan, T. (1994). Early domestic dogs in the Near East. Journal of Archaeological Science, 21, 633-640.

De Castro, J. J., James, A. D., Minjauw, B., Di Giulio, G. U., Permin, A., Pegram, R. G., et al. (1997). Longterm studies on the economic impact of ticks of Sanga cattle in Zambia. Experimental and Applied Acarology, 21, 3-19.

Di Lernia, S. (2001). Dismantling dung: delayed use of food resources among early Holocene foragers of the Libyan Sahara. Journal of Anthropological Archaeology, 20, 408-441.

Dolan, R. B. (1998). The Orma Boran: A trypanotolerant East African breed. Fifteen years of research on Galana Ranch in Kenya. Nairobi: KETRI (Kenya Trypanosomiasis Research Institute).

Driscoll, C. A., Macdonald, D. W., \& O’Brien, S. J. (2009). Colloquium papers: from wild animals to domestic pets, an evolutionary view of domestication. Proceedings of the National Academy of Sciences, 106, 9971-9978.

Duffy, D. C., Downer, R., \& Brinkley, C. (1992). The effectiveness of Helmeted Guineafowl in the control of the deer tick, the vector of Lyme Disease. The Wilson Bulletin, 164, 342-345.

Edwards, C. J., MacHugh, D. E., Dobney, K. M., Martin, L., Russell, N., Horwitz, L. K., et al. (2004). Ancient DNA analysis of 101 cattle remains: Limits and prospects. Journal of Archaeological Science, 31, 695-710.

Eriksson, J., Larson, G., Gunnarsson, U., Bed'hom, B., Tixier-Boichard, M., Strömstedt, L., et al. (2008). Identification of the yellow skin gene reveals a hybrid origin of the domestic chicken. PLoS Genetics, 4, e1000010. 
Evershed, R. P., Payne, S., Sherratt, A. G., Copley, M. S., Coolidge, J., Urem-Kotsu, D., et al. (2008). Earliest date for milk use in the Near East and southeastern Europe linked to cattle herding. Nature, $455,528-531$.

Fang, G., Larson, H., Ribeiro, S., Li, N., \& Andersson, L. (2009). Contrasting mode of evolution at a coat color locus in wild and domestic pigs. PLoS Genetics, 5, e1000341.

Fernández, H., et al. (2006). Divergent mtDNA lineages of goats in an early Neolithic site, far from the initial domestication areas. PNAS, 103(42), 15375-15379.

Gautier, A. (1984). Archaeozoology of the Bir Kiseiba region, Eastern Sahara. In F. Wendorf, R. Schild, \& A. E. Close (Eds.), Cattle-Keepers of the Eastern Sahara (pp. 49-72). Dallas: Southern Methodist University.

Gautier, A. (1987). Prehistoric men and cattle in North Africa: A dearth of data and a surfeit of models. In A. Close (Ed.), Prehistory of Arid North Africa. Essays in Honor of Fred Wendorf (pp. 163-187). Dallas: Southern Methodist University Press.

Gautier, A. (2002). The evidence of the earliest livestock in North Africa: or adventures with large bovids, ovicaprids, dogs and pigs. In F. A. Hassan (Ed.), Droughts, food, and culture: Ecological change and food security in Africa's Late prehistory (pp. 195-224). New York: Kluwer.

Germonpré, M., Sablin, M. V., Stevens, R. E., Hedges, R. E. M., Hofreiter, M., Stiller, M., et al. (2009). Fossil dogs and wolves from Palaeolithic sites in Belgium, the Ukraine and Russia: Osteometry, ancient DNA and stable isotopes. Journal of Archaeological Science, 36, 473-490.

Gifford-Gonzalez, D. (2000). Animal disease challenges to the emergence of pastoralism in sub-Saharan Africa. African Archaeological Review, 18, 95-139.

Giuffra, E., Kijas, J. M., Amarger, V., Carlborg, O., Jeon, J. T., \& Andersson, L. (2000). The origin of the domestic pig: Independent domestication and subsequent introgression. Genetics, 154, 1785-1791.

Götherström, A., Anderung, C., Hellborg, L., Elburg, R., Smith, C., Bradley, D. G. et al. (2005). Cattle domestication in the Near East was followed by hybridization with aurochs bulls in Europe. Proceedings of the Royal Society B 272, 2345-2350.

Grafton, R. N. (1971). Winter food of the helmeted guineafowl in Natal. Ostrich Supplement, 8, 475-485.

Gramly, M. R. (1972). Report on the teeth from Narosura. Azania, 7, 87-91.

Grigson, C. (1983). Very large camel from the upper Pleistocene of the Negev Desert. Journal of Archaeological Science, 10, 311-316.

Grigson, C., Zarins, J., \& Gowlett, J. A. J. (1989). Camel in Arabia: A direct radiocarbon date, calibrated to about 7000 BC. Journal of Archaeological Science, 16, 355-362.

Halstead, P., Collins, P., \& Isaakidou, V. (2002). Sorting the sheep from the goats: Morphological distinction between the mandibles and mandibular teeth of adult Ovis and Capra. Journal of Archaeological Science, 29, 545-553.

Hanotte, O. (2007). Origin and history of livestock diversity. In B. Richkowsky \& D. Pilling (Eds.), Section A. The State of the World's Animal Genetic Resources for Food and Agriculture (pp. 5-19). Rome: F.A.O.

Hanotte, O., Bradley, D. G., Ochieng, J. W., Verjee, Y., Hill, E. W., \& Rege, J. E. O. (2002). African pastoralism: Genetic imprints of origins and migrations. Science, 296, 336-339.

Hanotte, O., Ronin, Y., Agaba, M., Nilsson, P., Gelhaus, A., Horstmann, R., et al. (2003). Mapping of quantitative trait loci controlling trypanotolerance in a cross of tolerant West African N'Dama and susceptible East African Boran cattle. Proceedings of the National Academy of Sciences, 100, $7443-7448$.

Hanotte, O., Tawah, C. L., Bradley, D. G., Okomo, M., Verjee, Y., Ochieng, J., et al. (2000). Geographic distribution and frequency of a taurine Bos taurus and an indicine Bos indicus gamma specific allele amongst sub-Saharan African cattle breeds. Molecular Ecology, 9, 387-396.

Hassan, F. A. (2000). Climate and cattle in North Africa: A first approximation. In K. C. MacDonald \& R. M. Blench (Eds.), The origins and development of African Livestock: Archaeology, genetics, linguistics, and ethnography (pp. 61-86). London: UCL Press.

Helmer, D. (2000). Discrimination des genres Ovis et Capra à l'aide des prémolaires inférieures 3 et 4 et interprétation des âges d'abattage: l'exemple de Dikili Tash (Grèce). Anthropozoologica, 3, 29-38.

Hiendleder, S., Lewalski, H., \& Janke, A. (2008). Complete mitochondrial genomes of Bos taurus and Bos indicus provide new insights into intra-species variation, taxonomy and domestication. Cytogenetic and Genome Research, 120, 150-156.

Hiendleder, S., Lewalski, H., Wassmuth, R., \& Janke, A. (1998). The complete mitochondrial DNA sequence of the domestic sheep (Ovis aries) and comparison with the other major ovine haplotype. Journal of Molecular Evolution, 47, 441-448.

Hoeven, E., Fidalis, M. N., Leak, S. G. A., Geerts, S., Hanotte, O., \& Han, J. (2007). Introgression of the Sahelian breed into West African dwarf goats. In A. R. Njogu (Ed.), Proceedings of the 28th 
International Scientific Council for Trypanosomiasis Research and Control conference (pp. 622-626). Nairobi: African Union/IBAR.

Honegger, M. (2005). Kerma et les débuts du Néolithique africain. Genava n.s., 53, 239-249.

Ingram, C. J. E., Mulcare, C. A., Itan, Y., Thomas, M. G. T., \& Swallow, D. M. (2009). Lactose digestion and the evolutionary genetics of lactase persistence. Human Genetics, 124, 579-591.

Itan, Y., Powell, A., Beaumont, M. A., Burger, J., \& Thomas, M. G. (2009). The origins of lactase persistence in Europe. PLoS Computational Biology, 5(8), e1000491.

Kambarage, D. M. (1995). East Coast Fever as a continued constraint to livestock improvement in Tanzania: A case study. Tropical Animal Health and Production, 27, 145-149.

Kimura, B., Marshall, F. B., Chen, S., Rosenbom, S., Moehlman, P. D., Tuross, N. et al. (2010). Ancient DNA from Nubian and Somali wild ass provides insights into donkey ancestry and domestication. Proceedings of the Royal Society B, published online 28 July 2010, doi:10.1098/rspb.2010.0708.

Kukekova, A. V., Acland, G. M., Oskina, I. N., Kharlamova, A. V., Trut, L. N., Chase, K., et al. (2006). The genetics of domesticated behavior in canids: What can dogs and silver foxes tell us about each other? In E. A. Ostrander, U. Giger, \& K. Lindblad-Toh (Eds.), The dog and its genome (pp. 515-537). Cold Spring Harbor, NY: Cold Spring Harbor Laboratory Press.

Kumar, S. (2005). Molecular clocks: Four decades of evolution. Nature Review Genetics, 6, 654-662.

Lamprey, H. F., \& Waller, R. (1990). The Loita-Mara region in historical times: Patterns of subsistence, settlement and ecological change. In P. T. Robertshaw (Ed.), Early pastoralists of South-Western Kenya (pp. 16-35). Nairobi: British Institute in Eastern Africa.

Larson, G., Dobney, K., Albarella, U., Fang, M., Matisoo-Smith, E., Robins, E., et al. (2005). Worldwide phylogeography of wild boar reveals multiple centers of pig domestication. Science, 307, 1618-1621.

Lawrence, J. A., de Vos, A. J., \& Irvin, A. D. (1994a). Corridor Fever. In J. A. W. Coetzer, G. R. Thomson, R. C. Tustun, \& N. P. J. Kriek (Eds.), Infectious diseases of livestock with special reference to Southern Africa. Volume 1 (pp. 326-328). New York: Oxford University Press.

Lawrence, J. A., de Vos, A. J., \& Irvin, A. D. (1994b). East Coast Fever. In J. A. W. Coetzer, G. R. Thomson, R. C. Tustun, \& N. P. J. Kriek (Eds.), Infectious diseases of livestock with special reference to Southern Africa. Volume 1 (pp. 309-325). New York: Oxford University Press.

Linseele, V. (2010). Did specialized pastoralism develop differently in Africa than in the Near East? An example from the West African Sahel. Journal of World Prehistory, 23, 43-77.

Linseele, V., Van Neer, W., \& Hendrickx, S. (2007). Evidence for early cat taming in Egypt. Journal of Archaeological Science, 34, 2081-2090.

Liu, Y.-P., Wu, G.-S., Yao, Y.-G., Miao, Y.-W., Luikart, G. L., Baigf, M., et al. (2006). Multiple maternal origins of chickens: out of the Asian jungle. Molecular Phylogenetics and Evolution, 38, 12-19.

Loftus, R. T., MacHugh, D. E., Bradley, D. G., Sharp, P. M., \& Cunningham, P. (1994). Evidence for two independent domestications of cattle. Proceedings of the National Academy of Sciences of the United States of America, 91, 2757-2761.

Luikart, G., Gielly, L., Excoffer, L., Vigne, J.-D., Bouvet, J., \& Taberlet, P. (2001). Multiple maternal origins and weak phylogeographic structure in domestic goats. Proceedings of the National Academy of Sciences, 98, 5927-5932.

Luikart, G. H. F., Mashkour, M., England, P. R., \& Taberlet, P. (2006). Origins and diffusion of domestic goats inferred from DNA markers. In M. A. Zeder, D. G. Bradley, E. Emshwiller, \& B. D. Smith (Eds.), Documenting domestication: New genetic and archaeological paradigms (pp. 294-305). Berkeley: University of California Press.

Lupo, K. D. A dog is for hunting, In U. Albarella (ed.), Ethnozooarchaeology. Oxbow Press, Oxford (in press).

MacDonald, K. C. (1992). The domestic chicken (Gallus gallus) in sub-Saharan Africa: A background to its introduction and its osteological differentiations from indigenous fowls (Numidinae and Fancolinus sp.). Journal of Archaeological Science, 19, 303-318.

MacDonald, K. C. \& Edwards, D. N. (1993) Chickens in Africa: The importance of Qasr Ibrim. Antiquity, 67, 584-590.

Malek, J. (1997). The cat in ancient Egypt. British Museum Press, London.

Manning, K. M. (2008). Mobility strategies and their social and economic implications for Late Stone Age Sahelian pastoral groups: A view from the Lower Tilemsi Valley, eastern Mali. Archaeological Review from Cambridge, 23, 125-145.

Marshall, F. B. (2000). The origins and spread of domestic animals in East Africa. In K. MacDonald \& R. Blench (Eds.), African Livestock: The new synthesis, archaeology, linguistics, DNA (pp. 191-221). Washington, D.C.: UCL Press. 
Mburu, D. N., Ochieng, J. W., Kuria, S. G., Jianlin, H., Kaufmann, B., Rege, J. E. O., et al. (2003). Genetic diversity and relationships of indigenous Kenyan camel (Camelus dromedarius) populations: Implications for their classification. Animal Genetics, 34(1), 26-32.

Meadows, J. R. S., Cemal, I., Karaca, O., Gootwine, E., \& Kijas, J. W. (2007). Five ovine mitochondrial lineages identified from sheep breeds of the Near East. Genetics, 175, 1371-1379.

Medley, G. F., Perry, B. D., \& Young, A. S. (1993). Preliminary analysis of the transmission dynamics of Theileria-Parva in eastern Africa. Parasitology, 106, 251-264.

Mitchell, P. (2002). The Archaeology of Southern Africa. Cambridge: Cambridge University Press.

Muchadeyi, F. C., Eding, H., Simianer, H., Wollny, C. B. A., Groeneveld, E., \& Weigend, S. (2008). Mitochondrial DNA D-loop sequences suggest a Southeast Asian and Indian origin of Zimbabwean village chickens. Animal Genetics, 39, 615-622.

Mudida, N., \& Horton, M. (1996). Subsistence at Shanga: the faunal record. In M. Horton (Ed.), Shanga: The archaeology of a muslim trading community on the coast of East Africa (pp. 378-393). Nairobi: British Institute in Eastern Africa.

Muigai, A. W. T. (2003). Characterization and conservation of indigenous animal genetic resources: Genetic diversity and relationships of fat-tailed and thin-tailed sheep of Africa. PhD thesis, Department of Biochemistry, Jomo Kenyatta University of Agriculture and Technology, Juja, Kenya.

Mulei, C. M., Gitau, G. K. \& Mbuthia, P. G. (1995). Causes of calf mortality in Kabete area of Kenya. Onderstepoort. Journal of Veterinary Research, 62, 181-185.

Mwacharo, J. M., Bjørnstad, G., Mobegi, V., Nomura, K., Hanada, H. Amano, T. et al. (2010). Mitochondrial DNA reveals multiple introductions of domestic chicken in East Africa. Molecular Phylogenetics and Evolution. Online 5 December 2010, http://hdl.handle.net/10568/2682.

Naderi, S., Rezaei, H.-R., Pompanon, F., Blum, M. G. B., Negrini, R., Naghash, H.-R., et al. (2008). The goat domestication process inferred from large-scale mitochondrial DNA analysis of wild and domestic individuals. Proceedings of the National Academy of Sciences, 105, 17659-17664.

Newman, J. L. (1995). The peopling of Africa: A geographic interpretation. New Haven: Yale University Press.

Nowak, R. (1991). Walker's mammals of the world (5th ed.). Baltimore: The Johns Hopkins University Press.

O’Brien, S. J., Johnson, W., Driscoll, C., Pontius, J., Pecon-Slattery, J., \& Menotti-Raymond, M. (2008). State of cat genomics. Trends in Genetics, 24, 268-279.

O'Connor, T. P. (1997). Working at relationships: another look at animal domestication. Antiquity, 71, 149-156.

Ocaido, M., Siefert, L., \& Baranga, J. (1996). Disease surveillance in mixed livestock and game areas around Lake Mburo National Park in Uganda. South African Journal of Wildlife Research, 26, $133-135$.

Pang, J.-F., Kluetsch, C., Zou, X.-J., Zhang, A.-B., Luo, L.-Y., Angleby, H., et al. (2009). mtDNA Data indicate a single origin for dogs south of Yangtze River, less than 16, 300 years ago, from numerous wolves. Molecular Biology and Evolution, 26, 2849-2864.

Pereira, F., Queirós, S., Gusmaõ, L., Nijman, I. J., Cuppen, E., Lenstra, J. A., et al. (2009). Tracing the history of goat pastoralism: New clues from mitochondrial and Y chromosome DNA in North Africa. Molecular Biology and Evolution, 26, 2765-2773.

Pérez-Pardal, L., Royo, L. J., Beja-Pereira, A., Chen, S., Cantet, R. J. C., Traoré, A., et al. (2010). Multiple paternal origins of domestic cattle revealed by $\mathrm{Y}$-specific interspersed multilocus microsatellites. Heredity, 105, 511-519.

Peters, J. (1991). The faunal remains from Shaqadud. In A. E. Marks \& A. Mohammed-Ali (Eds.), The late prehistory of the Eastern Sahel (pp. 197-235). Dallas, TX: Southern Methodist University Press.

Plug, I. (1996). Domestic animals during the early Iron Age in southern Africa. In G. Pwiti \& R. Soper (Eds.), Aspects of African archaeology: Papers from the 10th congress of the Pan-African Association for Prehistory and Related Studies (pp. 515-520). Harare: University of Zimbabwe.

Porter, V. (1993). Pigs. A handbook to the breeds of the world. Mountfield, United Kingdom: Helm Information Ltd.

Porter, V., \& Mason, I. L. (2002). Mason's world dictionary of livestock breeds, types and varieties. New York: C.A.B International.

Radley, D. E., Brown, C. G. D., Cunningham, M. P., Kimber, C. D., Musisi, F. L., Payne, R. C., et al. (1975). East Coast Fever: 3. Chemoprophylactic immunization of cattle using oxytetracycline and a combination of theilerial strains. Veterinary Parasitology, 1, 51-60.

Ramírez, O., Ojeda, A., Tomàs, A., Gallardo, D., Huang, L. S., Folch, J. M., et al. (2009). Integrating Y-chromosome, mitochondrial, and autosomal data to analyze the origin of pig breeds. Molecular Biology and Evolution, 26, 2061-2072. 
Razafindraibe, H., Mobegi, A., Ommeh, V., Rakotondravao, S. C., Bjørnstad, G., Hanotte, O., et al. (2008). Mitochondrial DNA origin of indigenous Malagasy chicken. Annals of the New York Academy of Sciences, 1149, 77-79.

Roberts, C. J., \& Gray, A. R. (1973a). Studies on trypanosome-resistant cattle. I. The breeding and growth performance of N'Dama, Mutura and Zebu cattle. Tropical Animal Health and Production, 5, 211-219.

Roberts, C. J., \& Gray, A. R. (1973b). Studies on trypanosome-resistant cattle. II. The effect of trypanosomiasis on N'Dama, Mutura and Zebu cattle. Tropical Animal Health and Production, 5, 220-223.

Rossel, S., Marshall, F., Peters, J., Pilgram, T., Adams, M. D., \& O’Connor, D. (2008). Domestication of the donkey: Timing, processes, and indicators. Proceedings of the National Academy of Sciences, 105, 3715-3720.

Rossiter, P. B. (1994). Rinderpest. In J. A. W. Coetzer, G. R. Thomson, R. C. Tustun, \& N. P. J. Kriek (Eds.), Infectious diseases of Livestock with special reference to Southern Africa, Vol. 2 (pp. 735-757). New York: Oxford University Press.

Rowley-Conwy, P. (1988). The camel in the Nile Valley: New radiocarbon accelerator (AMS) dates from Qasr Ibrim. Journal of Egyptian Archaeology, 74, 245-248.

Rubin, C.-J., et al. (2010). Whole genome sequencing reveal loci under selection during chicken domestication. Nature, 464, 587-591.

Russell, N. (2002). The wild side of animal domestication. Society and Animals, 10, 285-302.

Savolainen, P., Zhang, Y.-P., Luo, J., Lundeberg, J., \& Leitner, T. (2002). Genetic evidence for an East Asian origin of domestic dogs. Science, 298, 1610-1613.

Sealy, J., \& Yates, R. (1994). The chronology of the introduction of pastoralism to the Cape, South Africa. Antiquity, 68, 58-67.

Sealy, J., \& Yates, R. (1996). Direct radiocarbon dating of early sheep bones: Two further results. South African Archaeological Bulletin, 51, 109-110.

Seipel, M., Zivnuska, C., \& Chisholm, J. (2004). Feed efficiency of rainbow broilers in pastured poultry systems. Indianapolis: National Conference of Undergraduate Research at Indiana University, Purdue University.

Skead, C. J. (1962). A study of the crowned guineafowl Numida meleagris coronata Gurney. Ostrich, 33, 51-65.

Smith, A. B. (2008). In H. Barnard \& W. Wendrich (Eds.), The archaeology of mobility: Old world and new world nomadism. Los Angeles: Cotsen Institute of Archaeology, University of California.

Spickett, A. M. (1994). Genetic resistance of livestock to infectious diseases and parasites. In J. A. W. Coetzer, G. R. Thomson, R. C. Tustun, \& N. P. J. Kriek (Eds.), Infectious diseases of livestock with special reference to Southern Africa, Vol. 1 (pp. 143-150). New York: Oxford University Press.

Spinage, C. A. (1986). The natural history of antelopes. New York: Facts on File.

Stahl, A. B. (1999). Perceiving variability in time and space: The evolutionary mapping of African societies. In S. K. McIntosh (Ed.), Beyond Chiefdoms: Pathways to complexity in Africa (pp. 39-55). Cambridge: Cambridge University Press.

Taha, F. A. (2003). Forecasting Egypt's poultry industry needs, USDA economic research services. DC: Washington.

Tawah, C. L., Rege, J. E. O., \& Aboagye, G. S. (1997). A close look at a rare African breed-The Kuri cattle of the Lake Tchad Basin: Origin, distribution, production and adaptive characteristics. South African Journal of Animal Science, 27(2), 31-40.

Tesfaye, A. T. (2004). Genetic characterization of indigenous goat populations of Ethiopia using microsatellite DNA markers. In Division of daily cattle breeding. National Dairy Research Institute, Karnal, India.

Tishkoff, S. A., Reed, F. A., Ranciaro, A., Voight, B. F., Babbitt, C. C., Silverman, J. S., et al. (2007). Convergent adaptation of human lactase persistence in Africa and Europe. Nature Genetics, 39, 31-40.

Trut, L. N. (1999). Early canid domestication: The farm fox experiment. American Scientist, 87, 160-169.

Vigne, J.-D., Guilaine, J., Debue, K., Haye, L., \& Gérard, P. (2004). Early taming of the cat in Cyprus. Science, 304, 259.

Vilà, C., Savolainen, P., Maldonado, J. E., Amorim, I. R., Rice, J. E., Honeycutt, R. L., et al. (1997). Multiple and ancient origins of the domestic dog. Science, 276, 1687-1689.

Waladde, S. M., Young, A. S., Ochieng, S. A., Mwaura, S. N. \& Mwakima, F. N. (1993). Transmission of Theileria parva to cattle by Rhipicephalus appendiculatus adults fed as nymphae in vitro on infected blood though an artificial membrane. Parasitology 107, 249-256.

Walther, F. R. (1972). Territorial behaviour in certain horned ungulates, with special reference to the examples of Thomson's and Grant's gazelles. Zoologica Africana, 7, 303-307. 
Wayne, R. K., Leonard, J. A., \& Vilà, C. (2006). Genetic analysis of dog domestication. In M. A. Zeder, D. G. Bradley, E. Emshwiller, \& B. D. Smith (Eds.), Documenting domestication: New genetic and archaeological paradigms (pp. 279-293). Berkeley: University of California Press.

Wayne, R. K., \& Ostrander, E. A. (2007). Lessons learned from the dog genome. Trends in Genetics, 23, $558-567$.

Wendorf, F., \& Schild, R. (1998). Nabta Playa and its role in Northeastern African prehistory. Journal of Anthropological Archaeology, 17, 97-123.

Wetterstrom, W. (1993). Foraging and farming in Egypt: The transition from hunting and gathering to horticulture in the Nile Valley. In T. Shaw, P. Sinclair, B. Andah, \& A. Okpoko (Eds.), The archaeology of Africa: Foods, metals, and towns (pp. 165-226). London: Routledge.

Wood, N. J., \& Phua, S. H. (1996). Variation in the control region sequence of the sheep mitochondrial genome. Animal Genetics, 27, 25-33.

Zeder, M. A. (2006). Archaeological approaches to documenting animal domestication. In M. A. Zeder, D. G. Bradley, E. Emshwiller, \& B. D. Smith (Eds.), Documenting domestication: New genetic and archaeological paradigms (pp. 171-180). Berkeley: University of California Press.

Zeder, M. A., Emshwiller, E., Smith, B. D., \& Bradley, D. G. (2006). Documenting domestication: The intersection of genetics and archaeology. Trends in Genetics, 22, 139-145.

Zeder, M. A., \& Hesse, B. (2000). The initial domestication of goats (Capra hircus) in the Zagros Mountains 10, 000 years ago. Science, 287, 2254-2257.

Zeder, M. A., \& Pilaar, S. E. (2010). Assessing the reliability of criteria used to identify mandibles and mandibular teeth in sheep, Ovis, and goats, Capra. Journal of Archaeological Science, 37, 225-242.

Zohary, D., Tchernov, E., \& Horwitz, L. K. (1998). The role of unconscious selection in the domestication of sheep and goats. Journal of the Zoological Society of London, 245, 129-135. 